\title{
The EU Water Framework Directive: Challenges and Prospects for Implementation in Ukraine
}

\author{
By Olena Yara ${ }^{1}$, Olena Uliutina ${ }^{2}$, Liudmyla Golovko ${ }^{3}$, Liliiy Andrushchenko ${ }^{4}$
}

\begin{abstract}
The purpose of our scholarly work is to carry out the analysis of main trends of development and features of harmonization of Ukrainian water legislation with the EU Water Framework Directive (WFD). Limited analysis of the WFD was made and challenges for its implementation in Ukraine were explored. Our study is organized around three major themes: river basin management, water resource protection and water monitoring. As a result of the study proposals for the improvement of Ukrainian environmental legislation were made. Based on comparison analysis differences and common problems of implementation of the WFD in Ukraine and EU member states were determined and recommendations for implementation of successful experience of EU countries in Ukraine were made.
\end{abstract}

Keywords: EU water policy, water legislation, water management, water quality, water resources

\section{State of the Aquatic Environment in Ukraine: Challenges for the Future}

Modern water management and environmental problems have not only national, but also international significance, became one of the main factors of national security of Ukraine. Environmentally unbalanced economic activities that use significant water resources for the needs of the production sector and cause water pollution, artificial alteration of natural regime of water objects led to degradation processes that began to prevail over self-renewable and self-cleaning ability of water systems.

Ukraine belongs to countries with relatively low water resources. The average perennial renewable volume of surface water is approximately $95 \mathrm{~km} 3$ per year, which is equivalent to 2,0 thousand $\mathrm{m} 3$ per person. In the low-water years the average perennial renewable volume of surface water is approximately 1.2 thousand $\mathrm{m} 3$ per person, which, according to UNESCO classification, characterizes Ukraine as a water insecure country. Water scarcity is observed almost everywhere, especially in the basins of the Lower Dnieper, Seversky Donets, Southern Bug, Ingul and Azov rivers (Hadzalo, 2015).

Every year the condition of rivers, lakes and groundwaters in Ukraine is deteriorating. The Law of Ukraine "On the Fundamentals of National Security of Ukraine" defines

${ }^{1} \mathrm{PhD}$., professor of the Department of Administrative and Financial Law of the National University of Life and Environmental Sciences of Ukraine, Dean of the Faculty of Law of the National University of Life and Environmental Sciences of Ukraine

${ }^{2} \mathrm{PhD}$., associate professor of the Department of Administrative and Financial Law of the National University of Life and Environmental Sciences of Ukraine, Deputy Dean of the Faculty of Law of the National University of Life and Environmental Sciences of Ukraine

${ }^{3} \mathrm{PhD}$., associate professor of the Department of International Law and Comparative Law of the National University of Life and Environmental Sciences of Ukraine

${ }^{4} \mathrm{PhD}$, associate professor of the Department of Law of Kyiv Cooperative Institute of Business and Law 
threats to national security in the environmental sphere, including irrational use of natural resources, deterioration of ecological status of water basins, pollution and deterioration of water quality, etc (Law of Ukraine "On the Fundamentals of National Security of Ukraine", 2003).

The water in the rivers of Ukraine is heavily polluted. The facts of contamination of water bodies with harmful and toxic substances have acquired a systemic character. In 2016 more than 2 billion cubic meters of drains were dropped into the water bodies, and officially only two thirds of them passed through the treatment facilities (Analytical note, 2017).

Analysis of contaminated waters shows that small rivers in Ukraine are more polluted than large ones. This is explained not only by their low water content, but also by insufficient protection. Every year, 5 million tons of salts fall into the reservoirs of Ukraine and this is a significant part of the sewage of the mining and metallurgical industry. At the same time, almost half of the mineral fertilizers and pesticides are washed from the fields into rivers. According to estimates of the Association of Fishermen of Ukraine, over ten thousand small rivers disappeared from the map of Ukraine during the years of independence (In Ukraine, small rivers disappear, 2017).

The assessment of the situation in Ukraine identified the following main problems of the water policy: natural shortage of water resources, as well as their uneven distribution across the territory and in time; depletion of water resources due to the large volume of water intake for economic needs; significant amount of pollutants entering the river due to discharges and flat-flush; excessive regulation of river runoff, which causes additional water loss for evaporation, slowing down of water exchange and, consequently, deterioration of water quality and riverbed degradation; large volume of water losses during transportation in water supply networks and irrigation systems (approximately 33 percent).

\section{Evolution of Water Management in Ukraine: Problems of Compliance with WFD}

According to article 363 of the Association Agreement between the European Union and the European Atomic Energy Community and their member states, of the one part, and Ukraine, of the other part, gradual approximation of Ukrainian legislation to EU law and policy on environment shall proceed in accordance with Annex XXX to this Agreement. According to this Annex Ukraine undertakes to gradually approximate its legislation to 29 Directives and Regulations within the stipulated time frames, including the Water Framework Directive.

Implementation of the WFD is very important for Ukraine, not only because of the need to comply with the Association Agreement between Ukraine and the European Union, but also because of the urgent need for progressive reforms and the introduction of European standards in the country. The purpose of the EU Water Framework Directive is to ensure the sustainable use of water resources by gradually reducing or completely eliminating pollution and other harmful effects on the environment. As a result of achieving this goal, all surface and groundwater bodies achieve a "good" status 
(ecological and chemical), all artificial and significantly altered water objects achieve "good" ecological potential (Voulvoulis, 2017).

In order to introduce the principle of basin management in Ukraine, changes to the legislation have already been made. Thus, in the article 13 of the Water Code of Ukraine it was established that the state administration in the field of water use and protection is carried out on a basin principle on the basis of state, target, intergovernmental and regional programs for the use, protection and reproduction of water resources. The national target program for the development of the water sector and the ecological improvement of the Dnieper river basin until 2021 provides for a set of measures for the implementation of the integrated water resources management system based on the basin principle. Also, the Law of Ukraine "On the Basic Principles (Strategy) of the State Environmental Policy until 2020" states that the system of public administration in the field of water protection requires urgent reform in the direction of the transition to integrated water resources management.

In 2016 the Law of Ukraine on October 4, 2016 №1641-VIII "On Amendments to Certain Legislative Acts of Ukraine regarding the implementation of integrated approaches to water management by basin principle" was adopted and entered into force in February 2017. The law proposes the introduction of hydrographic and water management zoning of the territory of Ukraine for the development of river basin management plans. The concept of the river basin management plan was introduced as a strategic planning document for the implementation of a program of measures that provide the basis for an integrated, ecologically and economically sustainable water management within the river basin for the long-term period. However, in Ukraine there is no National Water Resources Management Strategy approved at the governmental level. Regarding the Water Strategy, in Ukraine, the "Water Strategy of Ukraine for the Period up to 2025" was approved and recommended for publication by the decision of the Academic Council of the Institute of Water Problems and Melioration of the National Academy of Sciences of December 25, 2014 only as a scientific publication.

Currently in Ukraine there is no single state agency that would resolve problems of water management, water resources and water supply of the population. Water resources protection and management is carried out by the Ministry of Environment and Natural Resources, State Committee on Water Management and their local bodies, regional state administrations, regional water management departments, city, settlement and village councils. There is no clear hierarchy of responsibilities in the sphere of ensuring the state of water resources and their use between the listed bodies and there are no agreed priorities in water management and environmental policy. The existence of an extensive system of governing bodies leads to duplication of functions concerning water supply of the population and rational utilization and water conservation, and this, in turn, does not allow coordinated actions and effective implementation of planned tasks.

In EU countries, as in Ukraine, there is no single agency in charge of water policy. Water sector governance has been decentralized and/or devolved (Jaspers, 2003). The decentralized nature of directive implementation allows member states flexibility in developing scale-specific water management policy (Green et al., 2013). Water Framework Directive provides flexibility for developing water policy at the appropriate level, because geophysical circumstances differ per region (Keessen et al., 2010). But at 
the same time in the EU member states duplication of functions in the sphere of water management occurs not very often.

In our opinion, state integrated river basin information system should be created in Ukraine, which will contain data on the use and reproduction of water resources, protection and state of water resources, based on the results of water and environmental monitoring and water accounting which will serve as information basis for water management.

Another obstacle to the development of Ukraine's water sector is that the system of river financing is imperfect: the funds obtained from water users and water polluters at the local level are accumulated in the center and minimum resources are returned to the basin departments, which reduces their financial possibilities. The main reason for failure to comply with primary environmental protection measures is the underfunding of budget programs. For example, in Ukraine there is a state program aimed at clearing the riverbeds. According to Ostap Semerak, Minister of Ecology and Natural Resources of Ukraine, the amount of funding of this program is 200 thousand hryvnia per year. Financing has not been changed during three years and next year it will be the same. The experts say such funding is not enough to work out even one project (Ukraine turns to desert?, 2017). In the member states of the European Union, unlike Ukraine, river basin authorities are equipped with extensive executive powers and budgets (Moss, 2012).

\section{Monitoring of Water Status in Ukraine}

According to article 8 of the Water Framework Directive member states shall ensure the establishment of programmes for the monitoring of water status in order to establish a coherent and comprehensive overview of water status within each river basin district. Such programmes are still not developed in Ukraine. For today, in Ukraine there is no single monitoring system for either surface or groundwater, which operates on the basin principle and coordinates the activities of all subjects of state water monitoring. In contrast to the current system of monitoring of water resources in Ukraine, the Water Framework Directive applies the principle of multi-level monitoring which varies significantly by objectives. One of the characteristics of the WFD is an integrated approach. This also applies to the assessment of the state of surface water. In assessing the status of surface water bodies within the framework of the WFD, biological, physicochemical and hydromorphological qualitative elements are taken into account, which requires from the surface water monitoring network the ability to track various qualitative elements and use the collected data for assessment in accordance with the criteria set by the WFD.

The main disadvantages of modern water monitoring system in Ukraine are as follows: departmental fragmentation, which leads to duplication (very often water samples are taken by different laboratories in the same place, the date of sampling is not agreed, and the exchange of results is absent), non-compliance with the requirements for the number of sampling. Laboratories of different departments use different methods of analysis, sometimes it makes it impossible to compare the results. The quality of laboratory measurements also needs to be improved. Another problem is the deficit of modern analytical equipment of high sensitivity, which makes it possible to determine the 
concentrations of specific contaminants. The types of monitoring are not consistent with the relevant monitoring programs that are being implemented in the EU countries (Kravchenko, 2014). That is why in Ukraine it is necessary to bring hydrochemical monitoring in line with the requirements of the WFD, to organize a unified system of laboratories, to coordinate the activities carried out by them, to provide the laboratories with appropriate equipment and reagents. It is required to introduce effective mechanisms for monitoring water by introducing assessments of "ecological state" and "chemical state" of waters instead of maximum allowable discharges and maximum permissible levels which are now used as a basis for monitoring of water objects in Ukraine. Also it is necessary to organize water monitoring in order to obtain a coordinated and comprehensive survey of each river basin to assess its ecological and chemical status using the principle of multilevel monitoring.

\section{Protection of Water Bodies in Ukraine and the EU: Comparative Analysis}

According to article 2 (33) of the Water Framework Directive "pollution" means direct or indirect introduction, as a result of human activity, of substances or heat into the air, water or land which may be harmful to human health or the quality of aquatic ecosystems or terrestrial ecosystems directly depending on aquatic ecosystems, which result in damage to material property, or which impair or interfere with amenities and other legitimate uses of the environment. Thus, the Water Framework Directive focuses not only on the needs of water use, but on the protection of aquatic and terrestrial ecosystems, as well as on its natural background conditions.

According to Article 1 of the Water Code of Ukraine water pollution (surface and underground sources, internal sea waters and territorial sea) is the contamination of water bodies due to special water use, while the contaminant is a substance that is brought into the water as a result of human activities, such as water intake from water bodies using installations or technical devices, water use and discharge of harmful substances into water bodies, including water intake and discharge of harmful substances into water using reverse channel due to special water use. The main difference between Ukrainian and European legislation concerning the protection of water bodies lies in general approach to this problem. Water Code of Ukraine and the Water Directive are aimed at reduction of pollutants in water bodies and achievement of indicators of water quality. At the same time in the Water Code of Ukraine indicators of quality of water are sanitary and hygienic and refer to the protection of human health while the Water Framework Directive defines environmental indicators aimed at protection of ecosystems of water bodies (Cherkashina, M., Vystavna, Y., 2013).

Industrial accidents and as a consequence pollution of water resources became more frequent in Ukraine, that have demonstrated improper situation concerning the compliance by business entities, which activity is highly hazardous, with requirements of environmental legislation and ignoring of basic safety rules. This determines the necessity of increased attention of the legislator to solution of problems of prevention of such cases and increase of responsibility of business entities in this area. In Ukraine most of the laws on economic activities provide compensation for damage due to environmental pollution, but they are not sufficient to ensure the prevention and elimination of damage 
caused to the environment (Ladychenko, V., Golovko, L., 2017). In Ukraine it is necessary to review fines for water pollution. In the sphere of industrial production the principle of "contaminated-pay" should operate effectively. At present time the system of fines in Ukraine does not prevent physical and legal persons from pollution of water objects.

Environmental taxes in Ukraine should perform fiscal function - to promote filling special and state budget at the level of developed countries; improve environmental situation through the implementation of "polluter pays" principle, which means financial incentives to reduce pollution; encourage taxpayers to reduce negative environmental impact through introducing environmentally friendly, resource and energy saving technologies; be simple in declaration and payment, which require simplification of administration procedures and expansion of the range of tax agents. Considering the scale of ecological crisis in Ukraine the necessity of forming a new system of economic regulators of nature is obvious. Such system must not only accumulate funds for urgent actions, but primarily encourage economic entities to protect the natural environment. In Ukraine, insurance mechanisms of environmental risks are not regulated by legislation. According to the Law of Ukraine on insurance environmental insurance is not mandatory. As a result, practice of insurance for environmental risks is not developed. On the example of some EU countries we consider it appropriate to introduce mandatory environmental insurance for operators of environmentally hazardous activities.

\section{Conclusions}

Ukraine's legislation partly complies with the EU Water Framework Directive. One of the crucial principles of European water policy - the principle of river basin management is enshrined in the Water Code of Ukraine and some other legislative acts. Water Code of Ukraine states that management of water resources should be based on the basin principle, but at the same time there is no clear strategy for implementation of this principle in the form of a plan with defined deadlines. In Ukraine the transition from the administrative-territorial to basin water management needs improvement of legislation primarily in terms of establishment of law aimed at practical implementation of integrated water management by basin principle, such as the definition of key terms, hydrographic and water management division of the territory of Ukraine, clear division of powers between bodies involved in water sector management, public participation.

One of the major drawbacks of the basin management system in Ukraine is the lack of real mechanisms for economic regulation of water relations, as is the case in developed countries. There, the profitable part of payments for the use of water objects and resources in the basin is aligned with the total costs for achieving environmental standards of water quality and improvement of water facilities.

Financing of measures for restoration of water resources is carried out mainly from the state budget and in part, from local budgets, extrabudgetary funds for environmental protection and other sources. In the absence of the basin hierarchy, financial resources are dispersed; their formation is not put in line with the use of water resources and 
facilities. The indicated disadvantages are amplified by the imperfect system of legal regulation of the use and protection of water resources.

It is necessary to introduce new, more effective environmental regulators, such as various types of tax incentives, soft loans, flexible environmental taxes on goods that have negative environmental impacts, material encouragement of greening of production activities, differentiation of pricing according to environmental criteria that will make investing in environmental projects profitable. It is also necessary to amend existing economic instruments (environmental payments, penalties, environmental taxes, environmental funds).

On the example of EU countries in Ukraine the following measures should be taken in order to adapt Ukrainian legislation to the EU Water Framework Directive: inclusion in the Water Code of Ukraine provisions on river basin management plans which should comply with article 11 of the Directive; development of river basin management plans; development of the system of water-related issues monitoring; development and fixing in the legal framework assessment criteria of the river basin; adoption and implementation of provisions of the Directive concerning public information and consultation. It is necessary to create a single register of surface and underground water objects in Ukraine. Until now, a single record of water objects has not been carried out in Ukraine.

\section{References}

Analytical note on water and health issues of Ministry of Ecology and Natural Resources of Ukraine (2017). Retrieved from: https://menr.gov.ua/news/31881.html

Cherkashina, M., Vystavna, Y. (2013). Legislative aspects of water pollution in Ukraine and European Union: comparison of the principal determinants. Journal of Kharkov National University named after V.N. Karazin, Series "Law", 1062, 238-242.

Directive 2000/60/EC of the European Parliament and of the Council of 23 October 2000 establishing a framework for Community action in the field of water policy (2000), 1-73.

Green, O.O., Garmestani, A.S, Van Rijswick, H.F.M.W., Keessen A.M. (2013). EU water governance: striking the right balance between regulatory flexibility and enforcement? Ecology and Society 18(2). Retrieved from: http://dx.doi.org/10.5751/ES-05357-180210

Hadzalo, J. (2015). Water strategy for the period until 2025. Kiev: Institute of Water Problems and Melioration of NAAS.

In Ukraine, small rivers disappear - association of fishermen (2017). Available at http://www.bbc.com/ukrainian/news-42122287

Jaspers, F.G. (2003). Institutional arrangements for integrated river basin management. Water policy 5(1), 7790.

Keessen, A.M., Van Kempen, J.J.H., Van Rijswick, H.F.M.W., Robbe, J., Backes, C.W. (2010). European river basin districts: are they swimming in the same implementation pool? Journal of Environmental Law 22(2), 197-222.

Kravchenko, O., Demidenko, A., Shtuiak, S., Dyakov, O., Zakorchevna, N. (2014). Principles of Acquis Communautaire as a prerequisite for improvement of the water legislation of Ukraine. Lviv: Vidrodzhenna.

Ladychenko, V., Golovko, L. (2017). Implementation of European Environmental Policy in Ukraine: Problems and Prospects. European Journal of Sustainable Development, Volume 6, № 3, 333-339

Law of Ukraine "On the Fundamentals of National Security of Ukraine" (2003). Bulletin of the Supreme Council of Ukraine. - № 39. - St.351

Moss, T. (2012). Spatial Fit, from Panacea to Practice: Implementing the EU Water Framework Directive. Ecology and Society 17 (3), Retrieved from: http://www.ecologyandsociety.org/vol17/iss3/art2/ 
Ukraine turns to desert? (2017). Retrieved from: http://uain.press/articles/ukrayina-peretvoryuyetsya-napustelyu/

Voulvoulis, N., Arpon, K.D., Giakoumis, T. (2017). The EU Water Framework Directive: from great expectations to problems with implementation. Science of the Total Environment 575, 358-369. 